\title{
The Role of Perceived Organisational Support on Organisational Justice and Turnover Intent among Private Secondary Schools in Jos, Plateau State
}

\author{
Florence Nkonye Akinrinlola ${ }^{1}$, Nanfa Danjuma Kusa ${ }^{2}$, Shitnaan Emmanuel Wapmuk ${ }^{3}$ \\ ${ }^{1,2,3}$, Department of Business Administration, Faculty of Management Sciences, University of Jos, Nigeria.
}

\begin{abstract}
This study seeks to investigate the function of Perceived Organisational Support on the association between Organisational Justice and Turnover Intent. To achieve this purpose, three objectives were established: firstly to examine the relationship between Organisational Justice and Turnover Intent, secondly to examine the relationship between Perceived Organisational Support and Turnover Intent, and lastly to examine the role of Perceived Organisational Support on the relationship between Organisational Justice and Turnover Intent.A survey research design was used to collate data from a population of 1162 teachers of private secondary schools. The Taro Yameneformular was used to determine the sample size of 298 teachers randomly selected from private secondary schools in Jos. The data was cleaned, coded, and properly analysed using multiple regression analysis. The results of the findings indicated that there was a positive relationship between Organisational Justice and Turnover Intent, secondly there exist a negative relationship between Perceived Organisational Support and Turnover Intent and lastly, Perceived Organisational Support did not moderate the relationship between Organisational Justice and Turnover Intent. In conclusion, Organisational Justice should be planted in the perceptions of teachers as it helps to prevent turnover intent or outright turnover of teachers which could further help to enhance the performance of students in WASSCE. Also, the management of educational institutions should focus more on distributive and informational justice to further reduce Turnover Intent to the bearest minimum.
\end{abstract}

Keywords: Turnover intent, organizational justice, perceived organizational support, private secondary schools, teachers.

\section{INTRODUCTION}

$\mathrm{I}_{\mathrm{i}}$ today's world, organisations have realised that people, intellectual capital, and talents are critical to organisational success. Overtime, employee's pivotal role in creating and maintaining an organization's competitive advantage has been identified as key to organization's performance (Tanwar \& Prasad, 2016) and market positioning thereby resulting in the directing of all focus towards attracting, motivating and keeping hold of qualified employees. Ahmed, \& Lebai Othman, (2017) stressed that the behaviour and approaches of employees are a reflection of the practices of human resource management therefore employee turnover is a subject matter that is considered to be a silent danger that exists in organisation (Raabe, Frese, Beehr 2007) and by extension, a major determinant of organisation's performance. Employee turnover intention on the other hand has received much scholarly attention because turnover intent has been associated with actual voluntary turnover (Kim, Im, \& Hwang, 2015).

Turnover intent is the cognitive process of thinking, scheduling, and craving to leave a job (Feng \& Angeline, 2010) and this has been a reoccurring decimal among teachers who frequently make up their minds to quit their positions voluntarily (Wells and Peachey, 2010). Voluntary turnover is usually dysfunctional and can be most detrimental to the organization as Teachers who leave the organization are the most talented and smartest as their valuable experiences, talent, skills and knowledge will leave with them and thereby deteriorate the organisation's efficiency (Watrous, Huffman \& Pritchard 2006). In addition, 40-50\% of most novice teachers have a high expectancy rate to quit the profession after a few years of service (Tehseen, \& Ul Hadi, 2015). According to Mary (2010), there are a variety of outlooks on the motivation of teachers in Africa. In Nigeria, the situation is not farfetched as private school teachers are constantly being exposed to the thought of quitting or switching their jobs which affects the quality of relationship between teachers and students and could therefore be linked to the poor performance of students (Mary, 2010; Bryk \& Schneider, 2002; Hanushek \& Rivkin, 2010; Ingersoll \& May 2011) and can also impose high costs on the schools to replace teachers (Ingersoll 2004). Turnover intent which is the strongest predictor of turnover among educational institutions can be curbed when organizational Justice perception is considered (Griffith \& Hom, 2001). Organisational justice elucidates the degree of expressed equality as perceived in a workplace. In extension, the triggers of positive or negative work-related approach are expressed mainly by the degree to which the fairness is perceived (Gomam, Vem, \& Panshak, 2017) as it is one of the most important determinant of employee turnover intention (Coetzee, 2005; Lacity \& Iyer, 2008; Nadiri \& Tanova, 2010; Demir, Guney, Akyurek, Ugural, \& Aslan, 2017).

Organisational Support theory states that employees are likely to develop a more positive outlook towards the organisation if they perceive support from the organisation (Eisenberger, Huntington, Hutchison, \& Sowa, 1986; Allen, Shore \& Griffeth, 2003) even though, when negatively correlated with turnover intention and actual turnover, employees often respond to their organisation in kind 
(Sherony \& Green, 2002). Due to the dearth of literature regarding turnover intention among private school teachers, this study therefore seeks to explain the effect of perception of organizational justice on employee's turnover through the intervention of organisational support.

\subsection{Objectives Of The Study}

The overall objective of this study is to determine if employee's perceived organisational support moderates the effect on the relationship between organisational justice and turnover intent among Private Secondary School teachers in Jos, Plateau State. Specifically, this study shall seek to:

1. To examine the relationship between OrganisationalJustice and Turnover Intent of Private Secondary School teachers in Jos, Plateau State.

2. To examine the relationship between Perceived Organizational Support and Turnover Intent of Private Secondary School teachers in Jos, Plateau State.

3. To determine the role of Perceived Organisational Support on the relationship between Organisational Justice and Turnover Intent of Private Secondary School teachers in Jos, Plateau State.

\subsection{Hypotheses}

The following hypotheses were tested in this study

H1: Organizational justice has no significant effect on the turnover intent of private secondary school teachers in Jos.

H2: There is no significant effect of Perceived organizational support on turnover intent of private secondary school teachers in Jos.

H3: There is no moderating effect of perceived organizational support on the relationship between organizational justice and turnover intent of private secondary school teachers in Jos.

\subsection{Significance of The Study}

This study will constitute valuable contributions to the existing body of knowledge in the following areas:

\section{Policy significance}

This study will serve as a model for schools generally, especially private schools to make

effective policies on various aspects of the justice system and organizational support programs that will improve the loyalty of their teachers and reduce turnover intent in private schools.

\section{Practical significance}

The recommendations of this research when implemented will add value to human resources management and will also help school management in developing and implementing justicebased policies and procedures.

\section{Theoretical significance}

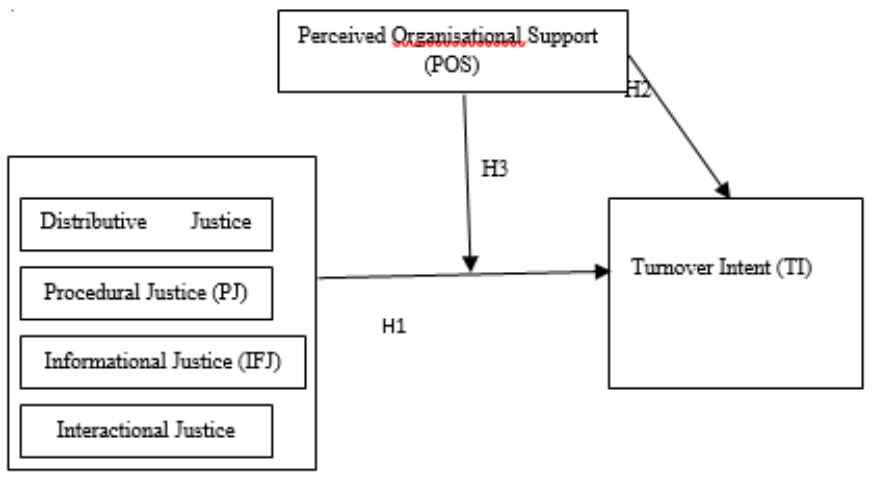

Figure 1: Conceptual Model

On the theoretical side, this study for the first time is considering organizational support in a moderating capacity in the model. The model has novelty in a private schools context. This will help in enriching the research on organizational justice and thereby add to available literature on organizational justice, organizational support, and turnover intent.

H3: There is no moderating effect of perceived organizational support on the relationship between organizational justice and turnover intent of private secondary school teachers in Jos.

\subsection{Significance of The Study}

This study will constitute valuable contributions to the existing body of knowledge in the following areas:

\section{Policy significance}

This study will serve as a model for schools generally, especially private schools to make

effective policies on various aspects of the justice system and organizational support programs that will improve the loyalty of their teachers and reduce turnover intent in private schools.

\section{Practical significance}

The recommendations of this research when implemented will add value to human resources management and will also help school management in developing and implementing justicebased policies and procedures.

\section{Theoretical significance}

On the theoretical side, this study for the first time is considering organizational support in a moderating capacity in the model. The model has novelty in a private schools context. This will help in enriching the research on organizational justice and thereby add to available literature on organizational justice, organizational support, and turnover intent.

\section{LITERATURE REVIEW}

\subsection{Conceptual Framework}

The research framework is developed from the contribution of previous studies. The study proposes a novel perspective to 
understanding turnover intent of employees through the predictive power of Organizational justice. Organizational Justice (distributive, procedural, interactional, informational) is proposed to associate directly with turnover intention. Additionally, organizational support is proposed to relate indirectly between OJ dimensions and Turnover intent. This model is depicted in figure 1 below:

\subsection{Empirical Review}

\subsubsection{Organisational Justice and Turnover Intent}

There are shared perspectives regarding turnover intent (Hellman, 1997; Hom and Griffeth, 1995; Griffeth, Hom \& Geatner, 2000; Price, 2001) as it commonly refers to the perceived probability or the eagerness to quit an organization by an employee. Extant studies have revealed that the best immediate predictor of actual turnover behaviour is turnover intent (Griffeth, et al, 2000; Price, 2001; Hemdi, 2006; Samad, 2006) with a positive relationship existing between turnover intent and the actual turnover (Lambert, Hogan, \& Barton, 2001; Mor Barak, Nissly, \& Levin, 2001; Price; 2001; Samad, 2006).

A study by Heydarian and Abhar (2011) and Tian-Foreman (2009) on the relationship between individual factors and its influence on intent to leave and individual's position revealed that those who occupy managerial position have low degree of turnover intent than those who are not. In addition, Quan and Cha (2010) revealed that the turnover intent among younger employees are higher than older ones while gender according to Ho, Sambasivan, Liew, (2013) has a significant relationship with turnover intent.

Extant studies have explored the effects of organizational justice on work-related variables, including turnover intent (e.g. Dailey and Kirk, 1992), and organizational behavior (e.g. Alexander and Ruderman, 1987). For example, Dailey and Kirk (1992) identified distributive and procedural justice as antecedents of job dissatisfaction and turnover intent. Loi, Lam, Chan (2012) also found that procedural justice is negatively associated with job insecurity and that this negative association is moderated by ethical leadership. Hence, employees' perceived organizational justice is associated with employees' turnover intention. The works of Rahim, Magner, Antonioni, Rahaman, (2001) and Lee (2000) found that distributive, procedural, and interactional justice had a significant effect on turnover intent; distributive justice had a significant negative effect on turnover intent, and procedural had a significant positive effect on turnover intent.

\subsubsection{Perceived Organizational Support and Turnover intent}

To ascertain the readiness of an organization to reward employees effort is determined by the extent their contributions are valued (Eisenberger et al 1986) which can be reciprocated by an increased loyalty and performance aimed at achieving organizational objectives (Kahumuza \& Schlechter, 2008; Eisenberger, Armeli, Rexwinkel, Lynch, \& Rhoades, 2001). Perceived organizational support being the major predictor of turnover intent creates the feeling of obligation in such a way that it's increase decreases the intent to quit (Tuzun \& Kalemci, 2012; Allen, et al 2003) and vice versa (Jawahar \& Hemmasi, 2006).

\subsubsection{The role of Perceived Organizational Support (POS)}

Employees' perceptions of an organization's value system is based on the passion and genuineness manifested by the organization through rewards or compliment (Tokmark, Turen, Gokmen, 2012; Beheshtifar \& Herat, 2013). In addition, perceived organizational support stimulates within employees the desire to help the organization to attain set goals (Aggarwal \& Bhargava, 2010) achieved by high performance (Armeli, Eisenberger, Fasolo, Lynch, 1998; Arshadi \& Hayavi, 2013; Aqeel and Ahmed, 2014; Eisenberger \& Stinglhamber, 2011; Campbell, Perry, Allen, Griffeth 2013) which reduces turnover intent.

\subsection{Theoretical Review}

\subsubsection{Social Exchange Theory}

This theory was propounded by Homans George (1974) who stated that the result of social

behavior is an exchange process which is focused at reducing cost and increasing benefits. The theory influences the exchange of any social relationship based on trust of reciprocity (Blau, 1964) through the use of subjective analysis anchored on people's desire to repeat rewarded actions (Homans, 1974). Social Exchange Theory has been used by previous researches to understand workplace behavior (Colquitt et al., 2013) and has been imported in this research to further explain the relationships and outcomes that may result in the presence or absence of a relationship between various variables.

Relevance of Social Exchange Theory: This theory is built on the principle of reciprocity as it becomes stronger when parties in the relationship are desirous to make available valuable resources to one another in the form of beneficial treatment from employers and commitment from employees. Previously, these exchanges have helped to explain the optimistic outcome which ensures organizational commitment. When an employee perceives fairness in an organization, he/she in exchange offers loyalty to the organization which reduces the intent to quite the organization.

\subsubsection{Theory of Planned Behaviour}

This theory assumes that; (1) hinges on the rationality and systematic use of available information by people when taking decision, (2) the actions or otherwise of people are guided by a conscious intent as against an unconscious one, and (3) the implications of an action is considered before decision is reached (Fishbein \& Ajzen, 1975; Ajzen \& Fishbein, 1980). According to Ajzen \& Fishbein, (1980), this theory was initially referred to as the theory of reasoned action whereby the subjective norm and approach of a person influences his 
behavioral intent and actual behaviour. Intent refer to those factors that has an influence on an individual's behavior or frequency to which a repeat of such behaviour is likely to take place (Ajzen, 1991).

According to this theory, therefore, when an employee's intent to quit the job becomes stronger, there is a very high likelihood of actually quitting. This theory helps to understand Turnover Intents as it relates to teachers of private secondary schools in Jos, Plateau State.

\subsubsection{Equity Theory}

Adam elaborated inputs such as effort, education, experience, age, and or attractiveness which can positively or negatively influence outcomes. This theory states that people compares their inputs and outcomes with others which helps them to evaluate their observation in a ratio. The comparison may either be with colleagues or from employees of other organizations. Internal comparison leads to perception of internal fairness. On the other hand, if there is a perception of inequity, resentment for being under-compensated or guilt for being over-compensated sets in (Adams, 1965)

The equity theory is established on the belief that the actions and motivation of employees are protected by organizational fairness. The theory further explained that the relationship that exists between employers and employees should be on a basis of an exchange relationship with fairness to all parties in the workplace. For an organization to work effectively, it paramount that fairness is perceived by the employees to be present. Furthermore, equity in terms of distributive, procedural, interactional, and informational justice influences employees' positive behaviours, the impression of unequal treatment may lead to an employee exhibiting negative behavioural outcomes.

According to Burus and Mattern (2010), equity theory is relates to employee's perception of the ways outcomes should be consistent with the norms or reward allocation. This theory further helps to throw more light and explain the significance of Organisational Justice as it concerns Turnover Intent.

\subsubsection{Organizational Support Theory}

Positive attitude towards the organization have the tendency of being developed whenever employees perceive support from the organization (Eiesnberger et al, 1986) as perceived organizational support tend to stimulate trust (Rhoades and Eisenberger, 2002) and a positive response (Sherony and Green, 2002) to the organization which will lead to a reduced search for alternative employment (Eisenberger, Fasolo, Davis-LaMastro, 1990).

\section{METHODOLOGY}

\subsection{Research Design}

A survey research design was adopted in this study which consisted of a population of 1164 teachers from 293 private secondary schools in Jos, Plateau State. From this population, the Yamene Taro (1976) formula was used to determine the same size of 298 teachers from private secondary schools in Jos, Plateau State

\subsection{Method of Data Analysis}

The data collected was sorted, coded and organized

before capturing the same in Statistical Packages for Social Sciences (SPSS Version 22.0 program) for analysis. After the coding, the data was cleaned for missing data, out-ofrange, and outliers. The assumptions of multiple regressions were assessed to check for normality of data, linearity, and multicollinearity of the independent variables. The evaluation of model fit with data was conducted and finally, multiple linear regression was conducted to test the direct relationship between the independent variable and the dependent variable.

The reliability and validity test of the research instrument shows a Cronbach Alpha equal to 0.7

therefore considered to be reliable and appropriate for measuring these constructs according to Nunnally (1967).

\section{DATA PRESENTATION AND ANALYSIS}

The questionnaires were distributed to 298 private secondary schools in Jos, Plateau State. Of the 298 distributed questionnaires, 277 were retrieved but only 247 were finally used for the data analysis after eliminating wrongly filled questionnaires giving a response rate of approximately $83 \%$.

\subsection{Demographic Characteristics of Respondents:}

Table 1: Questionnaire Distribution and Retention

\begin{tabular}{|c|c|}
\hline Description & Total \\
\hline Questionnaire Distributed & 298 \\
\hline Questionnaire Returned & 277 \\
\hline Questionnaire Wrongly Filled & 30 \\
\hline Questionnaire Retained & 247 \\
\hline
\end{tabular}

Source: Author

\subsection{Descriptive Statistics}

This section captures the characteristics of the respondents using gender, number of years in present employment, age, marital status, monthly income, and highest educational qualification.

Table 2: Gender Distribution of Respondents

\begin{tabular}{|c|c|c|}
\hline Respondent Characteristics & $\begin{array}{c}\text { Frequen } \\
\text { cy }\end{array}$ & $\begin{array}{c}\text { Percenta } \\
\text { ge }\end{array}$ \\
\hline Male & 146 & 59.1 \\
\hline Female & 101 & 40.9 \\
\hline Total & 247 & 100 \\
\hline
\end{tabular}

Source: SPSS Result 


\begin{tabular}{|c|c|c|c|c|c|}
\hline \multicolumn{6}{|c|}{ Table 3: Number of Years in Employment } \\
\hline & $\mathrm{N}$ & $\begin{array}{c}\text { Minim } \\
\text { um }\end{array}$ & $\begin{array}{c}\text { Maxim } \\
\text { um }\end{array}$ & $\begin{array}{c}\text { Me } \\
\text { an }\end{array}$ & $\begin{array}{c}\text { Std. } \\
\text { Deviati } \\
\text { on }\end{array}$ \\
\hline Years & 244 & 1 & 23 & $\begin{array}{c}2.6 \\
2\end{array}$ & 2.496 \\
\hline
\end{tabular}

Source: SPSS Result

Table 4: Age Distribution of Respondents

\begin{tabular}{|c|c|c|}
\hline Respondent Characteristics & $\begin{array}{c}\text { Frequen } \\
\text { cy }\end{array}$ & $\begin{array}{c}\text { Percenta } \\
\text { ge }\end{array}$ \\
\hline Less than 25 years & 14 & 5.7 \\
\hline 26-30 years & 70 & 28.3 \\
\hline 31-35 years & 64 & 25.9 \\
\hline 36-40 years & 63 & 25.5 \\
\hline 41-45 years & 17 & 6.9 \\
\hline 46-50years & 8 & 3.2 \\
\hline 51-55years & 4 & 1.6 \\
\hline 56-60years & 4 & 1.6 \\
\hline Above 60 years & 3 & 1.2 \\
\hline Total & 247 & 100 \\
\hline
\end{tabular}

Source: SPSS Result

Table 5: Marital Status of Respondents

\begin{tabular}{|c|c|c|}
\hline Respondent Characteristics & $\begin{array}{c}\text { Frequen } \\
\text { cy }\end{array}$ & $\begin{array}{c}\text { Percenta } \\
\text { ge }\end{array}$ \\
\hline Single & 80 & 32.4 \\
\hline Married & 145 & 58.7 \\
\hline Divorced/Separated & 11 & 4.5 \\
\hline Widowed & 11 & 4.5 \\
\hline Total & 247 & 100 \\
\hline
\end{tabular}

Source: SPSS Result.

Table 6: Monthly Income of Respondents

\begin{tabular}{|c|c|c|}
\hline Respondent Characteristics & $\begin{array}{c}\text { Frequen } \\
\text { cy }\end{array}$ & $\begin{array}{c}\text { Percenta } \\
\text { ge }\end{array}$ \\
\hline N10,000-N25,000 & 55 & 23.3 \\
\hline N26,000-N50,000 & 172 & 69.6 \\
\hline N51,000-N75,000 & 15 & 6.1 \\
\hline N76,000-N100,000 & 5 & 2.0 \\
\hline Total & 247 & 100 \\
\hline
\end{tabular}

Source: SPSS Result

Table 7: Educational Level of Respondents

\begin{tabular}{|c|c|c|}
\hline Respondent Characteristics & $\begin{array}{c}\text { Frequen } \\
\text { cy }\end{array}$ & $\begin{array}{c}\text { Percenta } \\
\text { ge }\end{array}$ \\
\hline NCE & 17 & 6.9 \\
\hline
\end{tabular}

a. Dependent Variable: Turnover Intent

b. Predictors: (Constant), Organizational Justice

c. Predictors: (Constant), Organizational Justice, OJ * POS

\begin{tabular}{|c|c|c|}
\hline B.A/B.Ed/B.Sc & 198 & 80.2 \\
\hline M.Sc/M.A./ED & 32 & 13.0 \\
\hline Total & 247 & 100 \\
\hline
\end{tabular}

Source: SPSS Result

\section{Regression Analysis - Overall Model Testing}

To explore the effect of organizational justice under the intervening role of perceived organizational support on turnover intent of private secondary school teachers in Jos, a sequential multiple regression analysis was employed. The outcome variable, which is turnover intent is influenced by organization justice and the interactive effect of organizational justice and perceived organizational support. Model fit was, therefore, assessed using the ANOVA table (Table 8) and Model Summary Table (Table 9). Table 8 reports the Fstatistics and its significance value while Table 9 reports the R, R-square, Adjusted R-square, R-square change, and sig. Fchange. Because this study includes a moderation analysis, two models were tested. Model 1 assessed the effect of organizational justice on turnover intent while Model 2 included a moderating effect of organizational justice and perceived organizational support on turnover intent.

As Tables 8 and 9 shows, Model 1 with organizational justice predicting turnover intent, $\mathrm{R}=0.204, \mathrm{R}^{2}=0.041$, Adjusted $\mathrm{R}^{2}$ $=0.038, \mathrm{R}^{2}$ change $=0.041, F(1,245)=10.595$ and $\mathrm{p}=0.01$. The inclusion of the interaction term of organizational justice and perceived organizational support in predicting turnover intent as captured in Model 2 improved the model fit of the regression analysis as reported by the following statistics: $\mathrm{R}=$ $0.209, \mathrm{R}^{2}=0.044$, Adjusted $\mathrm{R}^{2}=0.036, \mathrm{R}^{2}$ change $=0.02$, $F(2,244)=5.567$ and $\mathrm{p}=0.04$. The inclusion of the moderator variable (perceived organizational support) improved $\mathrm{R}^{2}$ from $4.1 \%$ to $4.4 \%$ with a significant change in the $R^{2}$ value implying that the moderator improves the effect of perceived organizational support on turnover intent private secondary school teachers in Jos.

Table 8: Anova

\begin{tabular}{|c|c|c|c|c|c|c|}
\hline \multicolumn{2}{|r|}{ Model } & $\begin{array}{l}\text { Sum of } \\
\text { Squares }\end{array}$ & df & $\begin{array}{c}\text { Mean } \\
\text { Square }\end{array}$ & $\mathrm{F}$ & $\begin{array}{l}\mathrm{Si} \\
\mathrm{g} .\end{array}$ \\
\hline \multirow{3}{*}{1} & Regression & 5.560 & 1 & 5.560 & $\begin{array}{c}10.5 \\
95\end{array}$ & $\begin{array}{c}.0 \\
01 \\
\mathrm{~b}\end{array}$ \\
\hline & Residual & 128.571 & 245 & .525 & & \\
\hline & Total & 134.131 & 246 & & & \\
\hline \multirow{3}{*}{2} & Regression & 5.853 & 2 & 2.927 & $\begin{array}{c}5.56 \\
7\end{array}$ & $\begin{array}{c}.0 \\
04 \\
c\end{array}$ \\
\hline & Residual & 128.278 & 244 & .526 & & \\
\hline & Total & 134.131 & 246 & & & \\
\hline
\end{tabular}




\begin{tabular}{|c|c|c|c|c|c|c|c|c|c|}
\hline \multirow[b]{2}{*}{ Model } & \multirow[b]{2}{*}{$\mathrm{R}$} & \multirow[b]{2}{*}{ R Square } & \multirow{2}{*}{$\begin{array}{l}\text { Adjuste } \\
\mathrm{d} R \\
\text { Square }\end{array}$} & \multirow{2}{*}{$\begin{array}{l}\text { Std. Error } \\
\text { of the } \\
\text { Estimate }\end{array}$} & \multicolumn{5}{|c|}{ Change Statistics } \\
\hline & & & & & $\begin{array}{c}\text { R } \\
\text { Square } \\
\text { Change }\end{array}$ & F Change & df1 & df2 & Sig. F Change \\
\hline 1 & $.204^{\mathrm{a}}$ & .041 & .038 & .724 & .041 & 10.595 & 1 & 245 & .001 \\
\hline 2 & $.209^{\mathrm{b}}$ & .044 & .036 & .725 & .002 & .558 & 1 & 244 & .456 \\
\hline \multicolumn{10}{|c|}{ a. Predictors: (Constant), Organizational Justice } \\
\hline \multicolumn{10}{|c|}{ b. Predictors: (Constant), Organizational Justice, OJ * POS } \\
\hline c. Depen & t Varia & Turnover I & & & & & & & \\
\hline
\end{tabular}

\subsection{Test of Hypothesis}

Hypothesis One

Hypothesis one states that organizational justice (distributive, procedural, interactional, and informational justice) has no significant effect on employees' turnover intent.

The result of the test of this hypothesis is captured in Table 10. Overall, organizational justice has a negative significant effect of turnover intentof teachers in private secondary schools in Jos as indicated: $\mathrm{B}=-0.185, \mathrm{t}=-0.326, \mathrm{p}<0.01$. Organizational justice accounts for 4.1 percent variation in turnover intent of private secondary school teachers in Jos. To explore which dimensions of organizational justice has the most influence on turnover intent; the four dimensions of organizational justice were regressed on turnover intent. As Table 10 indicates, distributive justice had a significant negative effect on turnover intent $(\mathrm{B}=-0.224, \mathrm{t}=-3.049, \mathrm{p}<$ 0.01 ) while informational justice has a positive significant effect $(B=0.162, t=2.356, p<0.01)$. Neither procedural $(B$ $=-0.122, \mathrm{t}=-1.578, \mathrm{p}=0.116)$ nor interactional justice $(\mathrm{B}=$ $0.006, t=0.088, p=0.930$ ) significantly predicted turnover intent of private secondary school teachers in Jos, Plateau State.

Table 10: Test of Hypothesis One

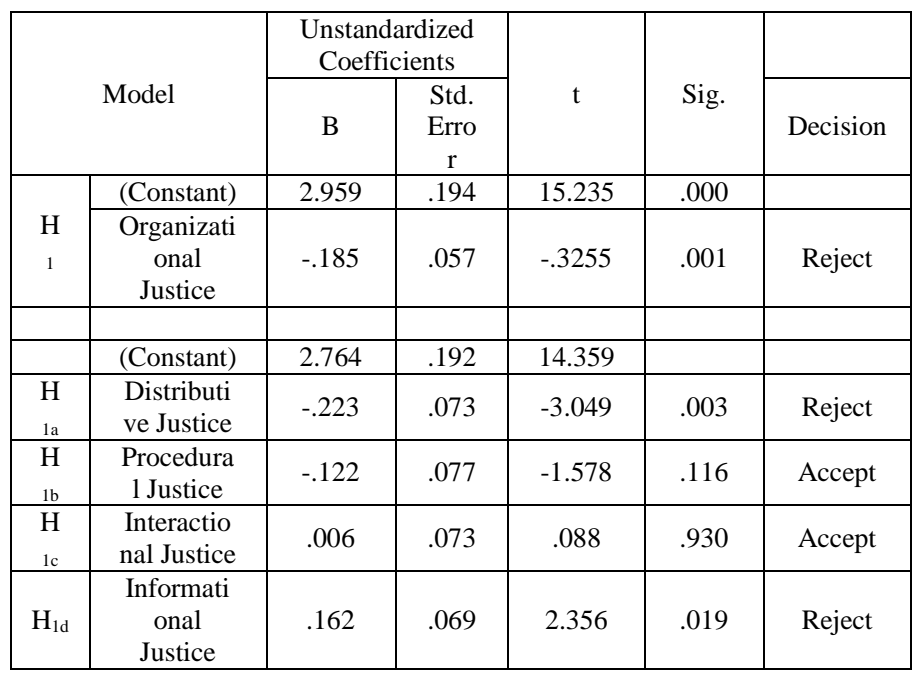

DV: Turnover Intent

Source: SPSS Result

\section{Hypothesis Two}

Hypothesis two states that perceived organizational support has no significant effect on employees' turnover intent.

The result of the regression analysis revealed that perceived organizational support has no significant effect on turnover

intent of teachers in private secondary schools in Jos, Plateau State as indicated: $\mathrm{B}=-0.09, \mathrm{t}=-1.938, \mathrm{p}=0.054$. The variation in turnover intent from perceived organizational support as captured by R-Square value is $1.5 \%$; that is, perceived organizational support explains only $1.5 \%$ of the variation in the turnover intent private secondary school teachers in Jos, Plateau State. This information is captured in Table 11.

Table 11: Test of Hypothesis Two

\begin{tabular}{|c|c|c|c|c|c|c|}
\hline & \multirow{2}{*}{ Model } & \multicolumn{2}{|c|}{$\begin{array}{l}\text { Unstandardized } \\
\text { Coefficients }\end{array}$} & \multirow{2}{*}{$\mathrm{T}$} & \multirow{2}{*}{ Sig. } & \multirow[b]{2}{*}{$\begin{array}{c}\text { Decisis } \\
\text { on }\end{array}$} \\
\hline & & B & $\begin{array}{l}\text { Std. } \\
\text { Error }\end{array}$ & & & \\
\hline \multirow[b]{2}{*}{$\mathrm{H}_{2}$} & (Constant) & 2.659 & .169 & 15.722 & .000 & \\
\hline & $\begin{array}{c}\text { Perceived } \\
\text { Organization } \\
\text { al Support }\end{array}$ & -.090 & .047 & -1.938 & .054 & $\begin{array}{c}\text { Acce } \\
\text { pt }\end{array}$ \\
\hline & $F_{(1,245)}$ & \multicolumn{3}{|c|}{3.756} & & \\
\hline & $\mathrm{R}^{2}$ & \multicolumn{3}{|c|}{.015} & & \\
\hline & Adjusted $\mathrm{R}^{2}$ & \multicolumn{3}{|c|}{.011} & & \\
\hline
\end{tabular}

DV: Turnover Intent

Source: SPSS Results

Hypothesis Three

Hypothesis three states that perceived organizational support does not moderate the relationship between organizational justice and employees' turnover intent.

The result of the sequential regression analysis support hypothesis three and is, therefore, accepted indicating that perceived organizational support does not moderate the relationship between organizational justice and turnover intent of private secondary school teachers in Jos, Plateau as indicated: $\mathrm{B}=0.014, \mathrm{t}=0.747, \mathrm{p}=0.456$. The interaction term explains about $4.4 \%$ of the variation in turnover intent. Table 12 shows this information 
Table 12: Test of Hypothesis Three

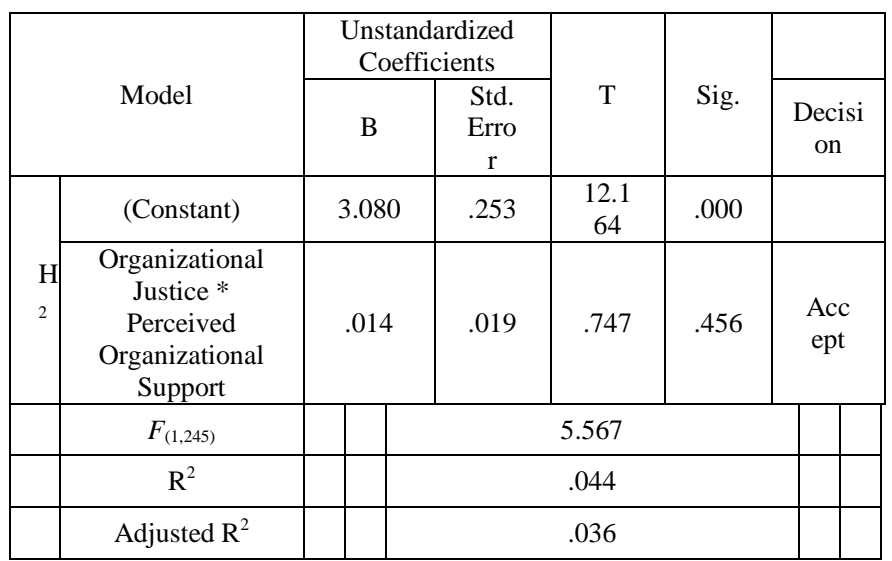

DV: Turnover Intent

Source: SPSS Result

\section{FINDINGS}

From the descriptive findings, the results showed that the majority of teachers in private secondary schools in Jos are males that are 40 years and below who are also married. The results also show that despite their high level of educational attainment, the majority of the teachers earn less than N50,000 per month and also do not have the intentof leaving their present employment. Lastly, the percentage of teachers that indicated whether they experience procedural, interactional, and informational justice and also organizational support in their present place of employment is higher compared to those who indicated that they experience less of it. For distributive justice, the percentage distribution is largely evenly distributed.

For the discussion regarding the test of hypothesis, the following discussion is made. Hypothesis one stated that organizational justice (distributive, procedural, interactional, and informational justice) has no significant effect on employees' turnover intent. Overall, organizational justice had a significant negative effect on the turnover intent private secondary school teachers in Jos. Especially while distributive justice and informational justice were significant predictors of turnover intent, procedural justice, and interactional justice were dimensions of organizational justice that were not significant predictors of turnover intent of teachers in private secondary schools in Jos, Plateau State. This finding agrees with the work of Fields et al. (2000), Addai, Kyeremeh, Abdulai, Sarfo, (2018), Zuraini, Sanjay, Noresah (2010).

Hypothesis two stated that perceived organizational support has no significant effect on employees' turnover intent. The analysis showed that perceived organizational support has no significant effect on turnover intent of teachers in private secondary schools in Jos, Plateau State. These findings gain support from empirical work by Jayasundera, Jayakody \& jayawardana 2017, Du Plesis, Barkhuizen, Stanz \& Schutte 2015, Perryer \&Jordan 2010, Kalidass \& Babron 2015 who also reported similar findings that perceived organizational support has a significant effect on employees' turnover intent.

Lastly, hypothesis three stated that perceived organizational support does not moderate the relationship between organizational justice and employees' turnover intent. The result of the analysis shows that perceived organizational support does not moderate the relationship between organizational justice and turnover intent of teachers in private secondary schools in Jos, Plateau State. This finding is supported by empirical research byDi Stefano, Venza, \& Aiello 2020, Loi et al. 2006 who also reported similar research conclusions.

\section{CONCLUSION AND RECOMMENDATIONS}

This study's objective was to determine if the employee's perceived organizational support moderates the effect on the relationship between organizational justice and turnover intent among Private Secondary Schools in Jos, Plateau State. Previous studies were reviewed and responses were analysed and tested. Based on this, the study discovered that organizational justice plays a significant role in the turnover intent of private secondary school teachers. There is also no significant relationship between perceived organizational support and turnover intent. Thus, organizational justice should be planted in the perception of the employees as it helps to prevent turnover intent or an outright turnover of the employees. In addition, perceived organizational support was observed not to play a significant role in moderating the relationship between organizational justice and turnover intent.

Based on the findings of this study, it was recommended that the influence of Organisational Justice in the turnover process has implications that should not be overlooked by $\mathrm{HR}$ Managers and effort should be geared towards a definite cautiousness of Human Resource practices which is not static but evolving. Supportive Human Resource practices should be instituted by every organization as the benefits of such practice in influencing turnover may be gradual but effective than a lack of such support. Secondly, the study exposed that informational justice and distributive justice has a significant relationship with the turnover intent of employees, therefore Human Resource managers are advised to ensure an open door policy for all staff as it helps to eliminate the perception that information is biased in its dissemination thereby breeding an intent to leave and also there should exist an equitable distribution of resources and rewards to further foster commitment and loyalty from teachers which can further help reduce Turnover Intent.

\section{SUGGESTIONS FOR FURTHER STUDY}

Future research should attempt to examine the effect of Organisational Justice dimensions (distributive, procedural, interactional, and informational justice) as it affects turnover intent across age, gender, and marital status to further affirm or negate this research work. 


\section{ACKNOWLEDGEMENT}

My profound gratitude goes to the staffs and lecturers of the School of Post Graduate Studies, University Of Jos, Nigeria for giving me the opportunity and empowering me with knowledge and experience to conduct this research.

\section{REFERENCES}

[1] Adams, J.S. (1965). Inequity in Social Exchange. Advances in Experimental Social Psychology, 2, 267-299. http://dx.doi.org/10.1016/S0065-2601(08)60108-2

[2] Addai, P., Kyeremeh, E., Abdulai, W., \& Sarfo, J. O. (2018). Influence of Organizational Justice and Job satisfaction on turnover Intentions among Teachers. European Journal of Contemporary Education, 7, 235-243.

[3] Aggarwal, U. \& Bhargava (2010). Examining Antecedents and Outcomes of Psychological Contract Breach: Mediating Role of trust. Academy of International Business, Rio Janeiro, Brazil.

[4] Ahmed, A., \& Lebai Othman, I. B. (2017). Relationship between organizational resources and organizational performance: A conceptualize mediation study. European Online Journal of Natural and Social Sciences, 6, 10-27. Retrieved from https://www.european-science.com/eojnss

[5] Ajzen, I. (1991). The theory of planned behavior. Organizational Behavior and Human Decision Processes, 50, 179-211

[6] Ajzen, I., \& Fishbein, M. (1980). Understanding attitudes and predicting social behavior. Englewood Cliffs, NJ: PrenticeHall

[7] Alexander, S., \& Ruderman, M. (1987). The role of procedural and distributive justice in organizational behavior. Social Justice Research, 1, 177-198

[8] Allen DG, Shore LM, Griffeth RW (2003). The role of perceived organizational support and supportive human resource practices in the turnover process. Journal of Management 29(1), 99-103.

[9] Aqeel, M., \& Ahmed, S. (2014). Relationship between Organizational Support and Job Performance. European Academic Research, 1(11), 4878-4885.

[10] Armeli, S., Eisenberger, R., Fasolo, P., \& Lynch, P. (1998). Perceived organizational support and police performance: The moderating influence of socio-emotional needs. Journal of Applied Psychology,83, 287-297

[11] Arshadi, N., \& Hayavi, G. (2013). The Effect of Perceived Organizational Support on Affective Commitment and Job Performance: Mediating Role of OBSE. Procedia - Social and Behavioral Sciences, $\quad 84, \quad 739-743$. https://doi.org/10.1016/j.sbspro.2013.06.637

[12] Beheshtifar, M., \& Herat, B. (2013). To promote Employees Commitment via Perceived Organizational Support. International Journal of Research in Business and Social Sciences, 3(1), 306313

[13] Blau, P. M.(1964) Justice in Social Exchange. Sociological Inquiry, $\quad 34, \quad$ 193-206.http://dx.doi.org/10.1111/j.1475682X.1964.tb00583.x

[14] Bryk, A.S. \& Schneider, B. (2002). Trust in schools: A core resource for improvement. New York: Russell Sage Foundation.

[15] Burrus, J., \& Mattern, K. D. (2010). Equity, Egoism, and Egocentrism: The Formation of Distributive Justice Judgments. Basic and Applied Social Psychology, 32, 155-164. http://dx.doi.org/10.1080/01973531003738593

[16] Campbell, N. S., Perry, S. J., Jr, C. P. M., Allen, D. G., \& Griffeth, R. W. (2013). All you need is resources: The effects of justice and support on burnout and turnover. Human Relations, 66(6), 759-782.

[17] Coetzee, M. (2005). The fairness of affirmative action: An organizational perspective. Unpublished Doctorial Thesis, University of Pretoria, Pretoria.

[18] Colquitt, J.A., Scott, B.A., Rodell, J.B., Long, D.M., Zapata, C.P., Conlon, D.E. et al. (2013). Justice at the millennium, a decade later: a meta-analytic test of social exchange and affect-based perspectives. Journal of Applied Psychology, 98(2), 199. https://doi.org/10.1037/a0031757

[19] Dailey, R. C. and D. J. Kirk. 1992. "Distributive andProcedural Justice As Antecedents Of Job Dissatisfaction and Intent To Turnover." Human Relations 45(3), 305-317

[20] Demir, M., Guney, S., Akyurek, S., Ugural, M. and Aslan, I. (2017). Effect of managers' organizational justice understanding on the level of employees' organizational commitment and job satisfaction. Expert Projects Publishing House. 146-65.

[21] Di Stefano, G., Venza, G., \& Aiello, D. (2020). Associations of Job Insecurity With Perceived Work-Related Symptoms, Job Satisfaction, and Turnover Intentions: The Mediating Role of Leader-Member Exchange and the Moderating Role of Organizational Support. Frontiers in psychology, 11, 1329. https://doi.org/10.3389/fpsyg.2020.01329

[22] Du Plesis, L., Barkhuizen, N., Stanz, K., \& Schutte, N. (2015). The management side of talent: casual implications for the retention of generation Y employees. The Journal of Applied Business Research, 31(5), 1767-1780

[23] Eisenberger, R., \& Stinglhamber, F. (2011). Perceived organizational support: Fostering enthusiastic and productive employees. American Psychological Association. https://doi.org/10.1037/12318-000

[24] Eisenberger, R., Armeli, S., Rexwinkel, B., Lynch, P. D., \& Rhoades, L. (2001). Reciprocation of perceived organizational support. Journal of Applied Psychology, 86(1),42-51. https://doi.org/10.1037/0021-9010.86.1.42

[25] Eisenberger, R., Fasolo, P., \& Davis-LaMastro, V.(1990). Perceived organizational support andemployee diligence, commitment, and innovation. Joumal of Applied Psychology. 75, 51-59.

[26] Eisenberger, R., Huntington, R., Hutchison, S., \& Sowa, D. (1986). Perceived organizational support. Journal of Applied Psychology, 71(3), 500-507. doi: 10.1037//00219010.71.3.500

[27] Fields, D., Pang, M., \& Chiu, C. 2000. Distributive and procedural justice as predictors of employee outcomes in Hong Kong. Journal of Organizational Behavior, 21(5), 547-562.

[28] Fishbein, M., \& Ajzen, I. (1975). Belief, attitude, intention and behavior: An introduction to theory and research. Reading, MA: Addison-Wesley.

[29] Gomam, G. M., Vem, L. J., \&Panshak, G. R., (2017). “Tetrad Effect of Perceived Justice Dimension on Normative Commitment, Psychological Ownership and Organizational Deviant Behaviour: A Conceptual Framework". International Journal of Advanced Scientific Research \& Development (IJASRD), 04 (04/I), 69 - 84.

[30] Griffeth, R. W., \&Hom, P. W. (2001). Retaining valued employees. Thousand Oaks, CA: Sage

[31] Griffeth, R. W., Hom, P. W., \& Gaertner, S. (2000). A MetaAnalysis of antecedents and correlates of employee turnover: Update, moderator tests, and research for the next millennium. Journal of management, 26, $463 \quad-488$. http://dx.doi.org/10.1177/014920630035

[32] Hanushek, e. \& Rivkin, s. (2010). Generalizations about using value-added measures of teacher quality." American economic Review. 100(2), 267-71.

[33] Hellman, C.M. (1997) Job satisfaction and the intention to leave. Journal of Social Psychology, 137, 677-689. doi:10.1080/00224549709595491

[34] Hemdi, M. A., \& Nasurdin, A. M. (2006). predicting turnover intentions of hotel employees: the influence of employee development human resource management practices and trust in organization. Gadjah Mada international journal of business, 8(1), $21-42$.

[35] Heydarian , M., \& Abhar, S. (2011). Factors contributing to employees' turnover intention. SEGi Review, 4(2), 31-41.

[36] Ho, J. A., Sambasivan, M. and Liew, E. Y. (2013) The relationship between job insecurity, shock, and turnover intention, amongst survivors of organizational downsizing. Pertanika Journal of Social Sciences \& Humanities, 21(spec. June), 101-114. 
[37] Hom, P. W. \& Griffeth, R. W. (1995). Employee Turnover. Cincinnati, OH: Southwestern College Publishing Ingersoll, R., \& May, H.(2011). Recruitment, retention and the minority teacher shortage. Retrieved from http://repository.upenn.edu/gse pubs/226

[38] Homans, G. C. (1974) Social Behaviour: Its Elementary Forms. Rev. ed. New York: Harcourt Brace Jovanovich, Inc.

[39] Ingersoll, R., \& May, H.(2011). Recruitment, retention and the minority teacher shortage. Retrieved from

http://repository.upenn.edu/gse pubs/226

[40] Jawahar, I., \& Hemmasi, P. (2006). Perceived organizational support for women's advancement and turnover intentions: The mediating role of job and employer satisfaction. Women in Management Review, 21, 643-661. doi:10.1108/09649420610712036

[41] Jayasundera, J. M. A., Jayakody, J. A. S. K., \& Jayawardana, A K. L. (2017). Perceived Organizational Support and Turnover Intention of Generation Y Employees: The Role of LeaderMember Exchange. Sri Lankan Journal of Management, 21(2), 136

[42] Kahumuza, J. and Schlechter, A. F. 2008. Examining the direct and some mediated relationships between perceived support and intention to quit. Management Dynamics 17 (3), 2-19.

[43] Kalidass, A., and Bahron, A. (2015). The relationship between perceived supervisor support, perceived organizational support, organizational commitment and employee turnover intention. Int. J. Bus. Adm. 6, 82-89. doi: 10.5430/ijba.v6n5p82

[44] Kim, S. S., Im, J., \& Hwang, J. (2015). The effects of mentoring on role stress, job attitude, and turnover intention in the hotel industry. International Journal of Hospitality Management, 48, 68-82. https://doi.org/10.1016/j.ijhm.2015.04.006

[45] Lacity, M.C. \&Iyer, P.S. (2008). Turnover intentions of Indian IS professionals. Information System Fronteirs, 10(2), 225-241.

[46] Lee H. (2000). An Empirical Study of Organizational Justice as a Mediator of the Relationship among Leader Member Exchange and Job Satisfaction, Organizational Commitment and Turnover Intention, Unpublished $\mathrm{PhD}$ Thesis Submitted to Faculty of the Virginia Polytechnic Institute and State University, Black-burg, Virginia.

[47] Loi, R., Lam, L. W., and Chan, K. W. (2012). Coping with job insecurity: the role of procedural justice, ethical leadership and power distance orientation. Journal of business ethics, 108, 36137

[48] Loi, R., Hang-Yue, N., \& Foley, S. (2006). Linking employees' justice perceptions to organizational commitment and intention to leave: The mediating role of perceived organizational support. Journal of Occupational and Organizational Psychology, 79(1), 101-120. https://doi.org/10.1348/096317905x39657

[49] Mary, A. (2010). Motivation and the performance of primary school teachers in Uganda: A case of Kimaanya-Kyabankuza division. (Unpublished PhD Thesis). Uganda: Makerere University.

[50] Nadiri H. \&Tanova C. (2010). An Investigation of the Role of Justice in Turnover Intentions, Job Satisfaction and Organizational Citizenship Behavior in Hospitality Industry. International Journal of Hospitality Management, 29, 33-41

[51] Nunnally, J. C. (1967). Psychometric theory. New York: McGraw Hill.
[52] Perryer C., \& Jordan C. (2010). Predicting turnover intentions. The interactive effects of organizational support. Management Research Review, 33(9), 911923

[53] Price, J. L. (2001). Reflections on the determinants of voluntary turnover. International Journal of Manpower, 22(7), 600 - 624.

[54] Quan, J. and Cha, H. (2010) IT certifications, outsourcing and information systems personnel turnover. Information Technology and People, 23(4), 330-351

[55] Raabe, B., Frese, M., \& Beehr, T. A. (2007). Action regulation theory and career self-management. Journal of Vocational Behavior,70(2),297-311. https://doi.org/10.1016/j.jvb.2006.10.005

[56] Rahim A. M; Magner R. N; Antonioni . D \& Rahaman S (2001). Do Justice Relationships with Organisation Directed Reactions differ across U. S and Bangladash Employees?.The International Journal of Conflict management, 12(4), 333-349.

[57] Rhoades, L. \& Eisenberger, R. (2002). Perceived Organizational Support: A Review of the Literature. Journal of Applied Psychology, 87(4), 98-714.

[58] Samad, S. (2006). Predicting turnover intentions: The case of Malaysian government doctors. Journal of American Academy of Business, 8(2), 113 - 119.

[59] Sherony KM, Green SG (2002). Coworker exchange: relationships between coworkers, leader-member exchange and work attitude, Journal of Applied Psychology. 87, 542-548

[60] Tanwar, K., \& Prasad, A. (2016). Exploring the Relationship between Employer Branding and Employee Retention. Global Business Review, 17(3), 186-206.

[61] Tehseen, S., \& Ul Hadi, N. (2015). Factors influencing teachers' performance and retention. Mediterranean Journal of Social Sciences, 6(1).

[62] Tian-Foreman, A. (2009). Job satisfaction and turnover in the Chinese retail industry. Chinese Management Studies, 3(4), 356378. https://doi.org/10.1108/17506140911007503

[63] Tokmark, I., Turen, U., \& Gökmen, Y. (2012). Exploring the Effects of Human Resources Management Practices on Organizational Performance and the mediating role of Perceived Organizational Support: An empirical research on Turkish SMEs. European Journal of Social Sciences, 36(2), 253-262

[64] Tuzun, I. K., \& Kalemci, R. A. (2012). Organizational and Supervisory Support in Relation to Employee Turnover Intentions. Journal of Managerial Psychology, 27, 518-534.

[65] Watrous, K.M., Huffman, A.H \& Pritchard, R.D., (2006). When Co-Workers and Managers Quit: The effect of Turnover and Shared Values on Performance. Journal of Business Psychology., 21,103-126.

[66] Wells, J.E., \&Pearchey, J.W. (2010). Turnover intention: Do leadership behaviors and satisfaction with leader matter? Team Performance management, 17(1), 23-40. http://dx.doi.org/10.

[67] Yamane, Taro. (1976). Statistics: An Introductory Analysis, 2nd Edition, Published by Frankfurt am Main : Fischer Taschenbuch Verlag

[68] Zuraini, Z., Sanjay, G. and Noresah. M. (2010). Effective Microorganism (EM) technology for water quality restoration and potential for sustainable water resources and management. 